\title{
ASO Visual Abstract: Retrospective Multicenter Analysis Comparing Conventional with Oncoplastic Breast-Conserving Surgery: Oncological and Surgical Outcomes in Women with High-Risk Breast Cancer from the OPBC-01/iTOP2 Study
}

Florian Fitzal, MD, MBA, FEBS ${ }^{1}$, Michael Bolliger, $\mathrm{MD}^{1}$, Daniela Dunkler, $\mathrm{PhD}^{2}$, Angelika Geroldinger, $\mathrm{PhD}^{2}$, Luca Gambone, $\mathrm{MD}^{1}$, Jörg Heil, $\mathrm{MD}, \mathrm{PhD}^{3}$, Fabian Riedel, $\mathrm{MD}^{3}$, Jana de Boniface, $\mathrm{MD}$, $\mathrm{PhD}^{4,5}$, Camilla Andre, $\mathrm{MD}^{4,6}$, Zoltan Matrai, $\mathrm{MD}, \mathrm{PhD}^{7}$, Dávid Pukancsik, $\mathrm{MD}$, $\mathrm{PhD}^{7}$, Regis $\mathrm{R}$. Paulinelli, $\mathrm{MD}$, $\mathrm{PhD}^{8}$, Valerijus Ostapenko, MD, PhD ${ }^{9,10}$, Arvydas Burneckis, $\mathbf{M D}^{9,10}$, Andrej Ostapenko, $\mathbf{M D}^{\mathbf{9 , 1 0}}$, Edvin Ostapenko, MD ${ }^{9,10}$, Francesco Meani, MD, CEBS ${ }^{11,12}$, Yves Harder, MD ${ }^{11,13,14}$, Marta Bonollo, MD ${ }^{11,12}$, Andrea S. M. Alberti, MD ${ }^{11,13,14}$, Christoph Tausch, $\mathrm{MD}^{15}$, Bärbel Papassotiropoulos, $\mathrm{MD}^{15}$, Ruth Helfgott, $\mathrm{MD}^{16}$, Dietmar Heck, $\mathrm{MD}^{16}$, Hans-Jörg Fehrer, $\mathrm{MD}^{16}$, Markus Acko, $\mathrm{MD}^{16}$, Peter Schrenk, $\mathrm{MD}^{17}$, Elisabeth Trapp, $\mathrm{MD}^{17}$, Pristauz-Telsnigg Gunda, $\mathrm{MD}^{17}$, Paliczek Clara ${ }^{17}$, Giacomo Montagna, MD, MPH ${ }^{18,19}$, Mathilde Ritter, MD ${ }^{18}$, Jens-Uwe Blohmer, MD ${ }^{20}$, Sander Steffen, MSc ${ }^{21}$, Laszlo Romics, $\mathrm{MD}$, $\mathrm{PhD}^{22}$, Elizabeth Morrow, $\mathrm{MD}^{23}$, Katharina Lorenz, $\mathrm{MD}^{24}$, Mathias Fehr, $\mathrm{MD}^{24}$, and Walter Paul Weber, MD $^{18,25}$

${ }^{1}$ Department of General Surgery and Breast Health Center, Medical University Vienna, Vienna, Austria; ${ }^{2}$ Center for Medical Statistics, Informatics and Intelligent Systems, Medical University of Vienna, Vienna, Austria; ${ }^{3}$ Departement of Obstetrics and Gynecology, Breast Center, Heidelberg University Hospital, Heidelberg, Germany; ${ }^{4}$ Department of Molecular Medicine and Surgery, Karolinska Institutet, Stockholm, Sweden; ${ }^{5}$ Department of Surgery, Capio S:t Göran's Hospital, Stockholm, Sweden; ${ }^{6}$ Department of Surgery, Uppsala University Hospital, Uppsala, Sweden; ${ }^{7}$ Department of Breast and Sarcoma Surgery, National Institute of Oncology, Budapest, Hungary; ${ }^{8}$ Federal University of Goiás, Araújo Jorge Hospital, Goiás Anti-Cancer Association, Goiás, Brazil; ${ }^{9}$ National Cancer Institute Vilnius Lithuania, Vilnius, Lithuania; ${ }^{10}$ Faculty of Medicine, University of Vilnius, Vilnius, Lithuania; ${ }^{11}$ Centro di Senologia della Svizzera Italiana (CSSI), Lugano, Switzerland; ${ }^{12}$ Department of Obstetrics and Gynecology, Ente Ospedaliero Cantonale (EOC), Lugano, Switzerland; ${ }^{13}$ Department of Plastic, Reconstructive and Aesthetic Surgery, Ente Ospedaliero Cantonale (EOC), Lugano, Switzerland; ${ }^{14}$ Faculty of Biomedical Sciences, Università della Svizzera Italiana (USI), Lugano, Switzerland; ${ }^{15}$ BreastCenter, Zurich, Switzerland; ${ }^{16}$ Department of Surgery, Ordensklinikum Linz - Sisters of Charity, Linz, Austria;

${ }^{17}$ Department of Obstetrics and Gynecology, Medical University of Graz, Graz, Austria; ${ }^{18}$ Breast Center, University Hospital of Basel, Basel, Switzerland; ${ }^{19}$ Breast Service, Department of Surgery, Memorial Sloan Kettering Cancer Center, New York, NY; ${ }^{20}$ Department of Gynecology and Breast Center, Charité University Hospital Campus Charité-Mitte, Berlin, Germany; ${ }^{21}$ Clinical Cancer Registry, Charité Comprehensive Cancer Center (CCCC), University Medical Center Berlin, Berlin, Germany; ${ }^{22}$ New Victoria Hospital, NHS Greater Glasgow and Clyde, Glasgow, UK; ${ }^{23}$ Department of Academic Surgery, University of Glasgow, Glasgow, UK; ${ }^{24}$ Department of Gynecology and Obstetrics, Cantonal Hospital, Frauenfeld, Frauenfeld, Switzerland; ${ }^{25}$ University of Basel, Basel, Switzerland

This study was presented in poster format at the 17th St. Gallen International Breast Cancer Conference 2021 (virtual meeting) and at the annual congress of the Austrian Society of Surgery 2021, virtual meeting.

(C) The Author(s) 2021

Published Online: 21 October 2021

F. Fitzal, MD, MBA, FEBS

e-mail: florian.fitzal@meduniwien.ac.at 
Recent data suggest that margins $\geq 2 \mathrm{~mm}$ after breastconserving surgery may improve local control in invasive breast cancer (BC). Data from consecutive high-risk BC in oncoplastic surgery increases the distance from cancer cells to the margin of the specimen and reduces re-excision rates significantly.

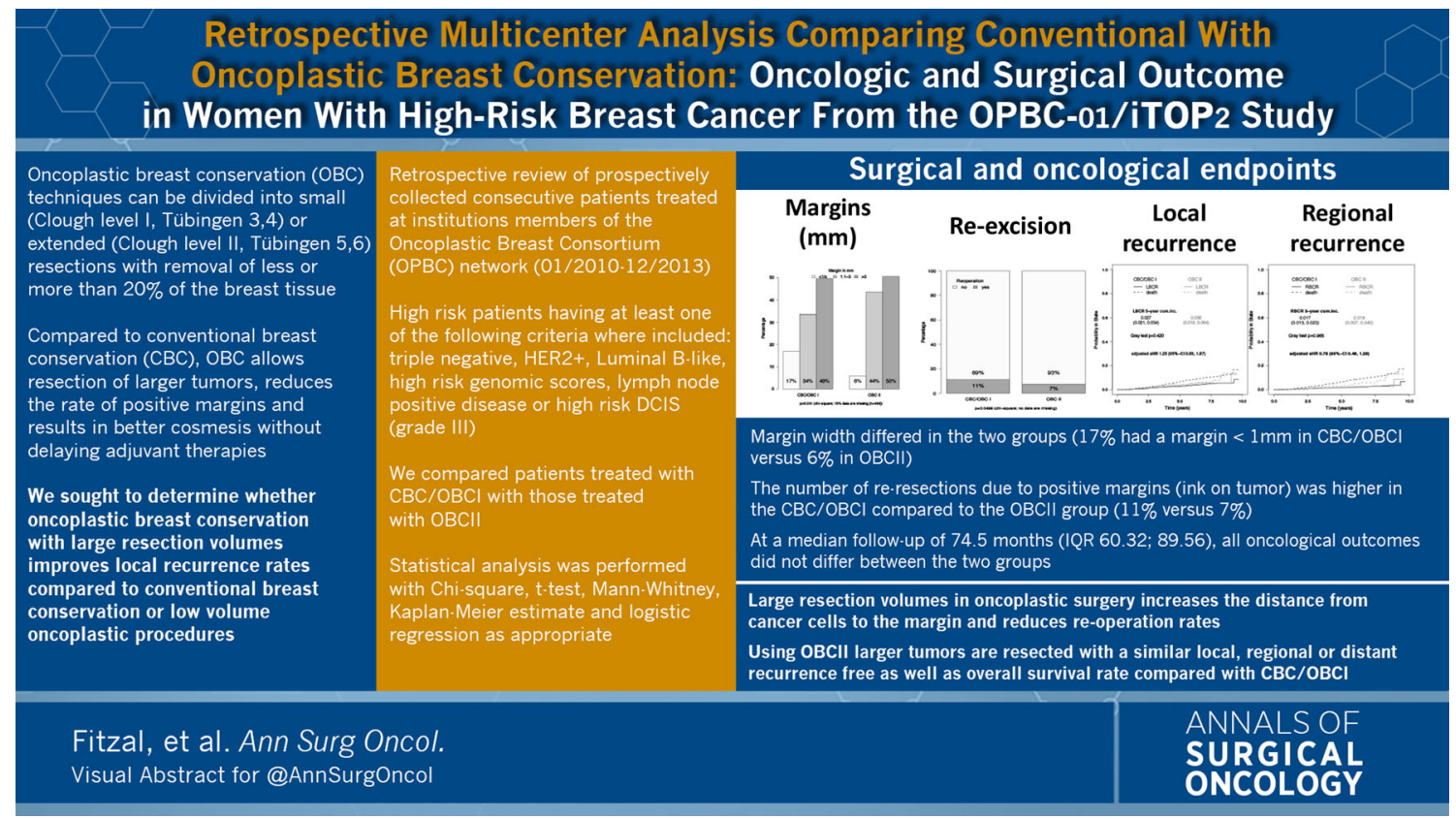

patients treated in 15 centers from the Oncoplastic Breast Consortium (OPBC) network, between January 2010 and December 2013, were retrospectively reviewed (https://doi. org/10.1245/s10434-021-10809-1). A total of 3177 women were included, $30 \%$ of whom were treated with OBC (OBCI, $n=663$; OBCII, $n=297$ ). Large resection volumes
ACKNOWLEDGEMENT F. Fitzal received personal honoraria and educational grants from Pfizer, Novartis, Roche, Astra Zeneca, Springer, Medtronic, and Bondimed. W.P. Weber has received research support from Takeda Pharmaceuticals International via Swiss Group for Clinical Cancer Research (SAKK), honoraria/consultation from Genomic Health, Inc., USA, and support paid to the University Hospital Basel for conferences and meetings from Sandoz, Genomic Health, Medtronic, Novartis Oncology, Pfizer, and Eli Lilly. 
AUTHOR CONTRIBUTIONS F.F. and W.P.W. developed the concept and initiated the study. All authors contributed substantially to the acquisition and analysis of data. D.D. conducted the statistical analysis. F.F., W.P.W., and G.M. drafted the manuscript. All authors helped to critically revise the draft for important intellectual content and read and approved the final version to be published. All authors agreed to be accountable for all aspects of the work in ensuring that questions related to the accuracy of any part of the work are appropriately investigated and resolved.

FUNDING None.

AVAILABILITY OF DATA AND MATERIALS F. Fitzal had full access to all the data in the study and takes responsibility for the integrity of the data and the accuracy of the data analysis.

DISCLOSURES No other authors have conflicts of interest disclosures to report.
OPEN ACCESS This article is licensed under a Creative Commons Attribution 4.0 International License, which permits use, sharing, adaptation, distribution and reproduction in any medium or format, as long as you give appropriate credit to the original author(s) and the source, provide a link to the Creative Commons licence, and indicate if changes were made. The images or other third party material in this article are included in the article's Creative Commons licence, unless indicated otherwise in a credit line to the material. If material is not included in the article's Creative Commons licence and your intended use is not permitted by statutory regulation or exceeds the permitted use, you will need to obtain permission directly from the copyright holder. To view a copy of this licence, visit http://creativecommons. org/licenses/by/4.0/.

Publisher's Note Springer Nature remains neutral with regard to jurisdictional claims in published maps and institutional affiliations. 